\title{
The Idea of the Feminine Beauty in the Italian Merchant Treaties of the XV Century
}

\author{
Paulina Piotrowicz \\ Jagiellonian University, Cracow, Poland
}

\begin{abstract}
In the context of Italian literature of 15 th century investigate the conception of beauty present in treatises considering the concept of family means not limited value of women's beauty. Examination of the course of the development of this idea leads to the conclusion that the conception of beauty doesn't exhaust itself in the traditional Aristotelian vision but implies a connection with virtu and with human values on which is based the society. In my analysis I will proceed comparing the visions of three authors which apparently belong to different environments but have the same cultural roots. In my investigation of the concept of beauty present in Francesco Barbaro's "De re uxoria", Leon Battista Alberti's "I libri della famiglia" and Benedetto Cotrugli's "Il libro dell'arte di mercatura", I will trace the definition of beauty which is far from simple physical gracefulness but is based on Aristotelian system of virtues. In that light it plays a major role in the formation of perfect citizen and in the utopian vision of the state.
\end{abstract}

Keywords: beauty, family, merchant, italian literature

\section{Introduction}

The greek word kalós - beauty indicates also a vocation or strong inclination to something, therefore to experience the beauty means to be encouraged to act in accordance with its rules (Kawecki, 2013, p. 11). Hence the necessity to define the nature of the beauty, a research which has been going on since the ancient times and it seems to be far from being exhausted. It is because the beauty forms part of the most important human's values which lead him to a sphere not perceptible by senses, leaving behind the physical and corporal reality. The identification of the beautiful with the good is therefore direct a consequence of a vision of universe understood as a perfect entity as a whole which structure is the highest expression of order, measure and form. If for Cicero "Nihil omnium rerum melius est mundo, nihil praestabilius, nihil pulchrius: nec solum nihil est, sed ne cogitari quidem quidquam melius potest. Et, si ratione e sapientia nihil est melius, necesse est haec inesse in eo, quod optimun esse concedimus" (Ciceronis, 1824, p. 78), in the good, then, there must be expressed values like unity, truth and goodness, because there is nothing more beautiful than the universe which is characterised by them (Eco, 1987, p. 29). Therefore the fusion of both physical and intangible beauty with the virtue is in act in every being in accordance with the Aristotelian rule of the virtue:

Paulina Piotrowicz, M.A in italian studies, Instiutie of Romance Studies, Jagiellonian University. 
The virtues, too, must be something good; for it is by possessing these that we are in a good condition, and they tend to produce good works and good actions. They must be severally named and described elsewhere. Pleasure, again, must be a good thing, since it is the nature of all animals to aim at it. Consequently both pleasant and beautiful things must be good things, since the former are productive of pleasure, while of the beautiful things some are pleasant and some desirable in and for themselves (Aristotle, I, 9, 1366a, 33).

In this perspective the beauty becomes a moral category which is related to aristotelian form since it is it that models the the matter, that is to say the human being otherwise empty vessel. The beauty, in the moral and civil perspective, and the good are one. Together they are the bases of values, backbones of the society of the XIV century. At the time of the formation of the society based on ideas of civil humanism, the awareness that the soul and the body, the form and the matter are subjected to the same laws which make the world perfectly harmonious, entails the need to establish some principles to escape to. If the beauty expresses itself in the every single element of both macro and microcosm, the social reality of men needs to be reorganised on the basis of the dialectic of decorum and measure. Consequently, the urgency to define and to insert the concept of the beauty in to a framework, especially in the context of Italian literature of XIV century and treaties about governance of the family, expresses in all its comprehensiveness how much the aesthetic notion of the beauty is anchored to the ethic in his practical perceptive.

This way comprehension of the phenomenon of the beauty is related to the concept of kalokagathia. Its meaning is included in a finding of the Oracle of Delphi who says that what is the most right is the most beautiful (Eco, 2005, p. 38). Next to the virtue matched with the beauty, greek philosophers draw their attention on the utility of the beauty or more specifically on the beauty of the useful:

(...) one thing is good and another noble? Don't you know that all things are noble and good for the same things? For, first, virtue is not something good for some things and noble for other things; next, human beings are said to be noble and good in the same respect as well as for the same things; the bodies of human beings, too, appear noble and good for the same things; and all other things that human beings use are held to be noble and good for the same things-whatever they are useful for." "Then," he said, "is even a dung-carrying basket noble?" "By Zeus," he said, "and a gold shield is shameful (ugly), if for their own work one should be nobly made, and the other badly. (Xenophon, Memorabilia, pp. 1-7).

Consequently, any person and any object can be called beautiful as long as works according to his purposes. This is a matter which returns many times during the discussion over the perfect humanistic citizen in the XV century. In the microcosms of the society the beauty of its single elements reflects itself only in the usefulness as well as in the equilibrium. Through this balance the chaos is stopped and any excess, harmful for the principle of the proportion and harmony, is contained by the measure.

The medieval ideas of beauty of Saint Thomas reinterpreted in humanistic view is still valuable in the debate of XV century about the education of model citizen and about the formation of the utopian vision of the State. The beauty then requires, as Saint Thomas says, qualities as integritas, proportio and finally claritas (Eco, 2005, p. 109) but interpreted not in the aesthetic perspective but in the ethical one: For beauty includes three conditions, "integrity" or "perfection," since those things which are impaired are by the very fact ugly; due "proportion" or "harmony"; and lastly, "brightness" or "clarity," hence things are called beautiful if have a bright colour (Aquinas, I, 39, 8). The proportion gains an ethic value since a virtuous action activates a right dose of act according to a rational law (Eco, 2005, pp. 88-90): “(...) beauty or comeliness results from the concurrence of clarity and due proportion. (...) In such manner spiritual beauty consists in a man's conduct or actions being well 
proportioned in respect of the spiritual clarity of reason" (Saint Thomas, II-II, q. 145, a. 2). Therefore everyone is gifted at carrying out properly his role which is crucial for the new society which considers on the one hand every single citizen architect and, on the other hand, the society itself as an opus to which is necessary gives the major disposition to the desired aim (Saint Thomas, II-II, q. 145, a. 2). To get to the perfection also through the integrity that is the presence in an organic whole of every single part which contribute to define it as such (Eco, 2005, p. 118) permits and an entity to work according to its intrinsics rules. The human being becomes an complete organism only if it is able to combine this qualities. From that moment every part coexists in a perfect order conformable to the norm of perfect adaptation of the matter to the form.

In order to investigate the idea of the beauty exposed by three exponents of Italian humanism which I will present here, apparently coming from different environment but still having the same cultural roots, it is necessary to look into the relation between the Nature, art and the beauty. This triangle has an relevant importance not only for the visual arts and the concept of ethicist but also for the notion of mimesis understood as the base of the moral system. It is because the mimesis regains from different models and in the end proposes an exemplar value of it. The definition of the terms ars and techno, valid both in ancient Greece and Rome and at the beginnings of modern age, indicates the capacity of creating something according to the rules in order to get an item which fulfils reason for which was created. Hence, the word art refers not strictly to the mere act of manufacturing but also relates to other area of human life (Diodato, De Caro, Boffi, 2009, p. 11). This special form of human activity requires specific talents and characteristics (ingenium, vena, proprium)of artefix (Fulińska, 2000, p. 11). In that sense, the concept of mimesi, comprehended according to the theory of Aristotle as an emulation of the reality with emphasis on the relation between the piece, results of human invention, and the nature, can be apply also to civil education. Consequently the men's duty is fulfilled by improving not only his nature but also the nature of what surrounds him. This kind of effort demands the Ciceronian dignity and severity of character. In the civil beauty order and measure are combined, the decorum which rules every element of a dynamic and plastic form in the spirit of "Virtus enim convenientia constat: omnia opera eius cum ipsa concordant et congrunt" (Seneca, VIII, 74, 30). This way to form a civil human being means to complete latent seeds of virtue (Garin, 1981, p. 123), which is nothing else but the beauty hidden under the guise of the interior harmony captured by the intellect. In this context mimesis represents the capacity to have an impact on the nature and to transform it in order to demonstrate the virtue in daily life and to make social coexistence possible. In that case, the virtue and in a wider prospective the beauty can be raised to be the men's major vehicle of communication with the external reality.

Considering the background, we will proceed with the analysis of women's beauty's idea in Benedetto Cotrugli's treaty "The book of the art of trade" in comparison with Francesco Barbaro's "De re uxoria". Each of them treats the issue of family governance and it's authors were one of the most important exponents of italian humanism. The interest in the women figure is related to the necessity of the new social groups born inside the system based on civil humanism's precepts to create their identity as well as distinct themselves from the rest of society. It is also important to precise the roles to play for the members of this groups. In such circumstances the phenomenon of the books dedicated to choice of the perfect spouse in order to control has its roots, in every detail, the family life under men's authority. This type of organisation of the household correspond to the power of the State over the citizens which has to guarantee civil order based on organisation, centralisation and rationalisation 
(Chojnacki, 2008, pp. 27-52) in the name of common good. Next to large number of topics regarding such problem, raise interest in the question of the nature of the feminine beauty. It seems to stop over purely formal matter which escape from an immediate solution but actually it leads to some conclusions which go beyond the notion of the beauty rooted into the tradition without running out in the vision of aristotelian or platonic origin. On the other hand it implies the relation between the virtue and this kind of values which are based of the society. In this regard the three above-mentioned volumes place themselves in this context.

Francesco Barbaro is one of the well known representative of italian humanism and it is not necessary to give him a detailed presentation. Benedetto Cotrugli on the other hand is better known as one of the first theorists of double entry (Bartić, 1995, pp. 121-241) although his book fall within literacy and cultural context of humanism. Cotrugli was born in 1410 (according to M. Luzatti in 1416) in Ragusa (Dubrovnik) in a merchant family. His father Giacomo hold some important position at the court of Giovanna II of Naples and he obtained important privileges which helped him to carrying out his activity. Moreover, also other members of Cotrugli family were involved in the trade business of the city of Ragusa and they often travelled in diplomatic mission. Benedetto, after a short period of study on the peninsula, was obliged to return home after his father's death in order to undertake the family business which rotated around his hometown and quickly expanded until Naples, Sicily, North Africa, Florence and Catalonia. In 1451, thanks to the position gained by his father, Cotrugli moved to Naples where he became an important figure at the court of Alfonso of Aragona and after his son Ferdinand. At the time he abandoned his merchant activity almost completely and he dedicated to administrative and diplomatic activities on behalf of the king. He died in 1469. In our times two of his book preserved ${ }^{1}$, above-mentioned The book of the art of trade, written in 1458 in vernacular language composed by fourth books each one on various issues. It treats the matters of trade, his nature and forms, of religion and moral life of the merchant and in the end of governance of the house and the family. De navigatione instead speaks about navigation and maritime subjects, it is written in vernacular language and it is prefaced by introduction in latin directed to the venetian senators (Falchetta, 2009). This book highlights Cotrugli's deep cultural and commercial knowledge which proves his connection with the most important cultural centres at the time as Venice, Florence and Naples. Right at the court of Ferdinand of Aragona he gets into contact with Gianozzo Manetti who speaks about him at his De terremotu which describes the earthquake at 1456. Manetti, telling about strange phenomenons preceding the the disaster, mentions Cotrugli:

(...)Primum igitur ex precendentibus signis consuevisse aiunt cum volucres sine aliqua firmitudine ac quiete hinc inde sponte sua volitare videntur; ac presertim si alquid egregium preter earum naturam operantur, ceu si galline acutos quosdam gallorum gallinaceorum cantus imitarentur, quemadmodum paucis antequam primus ex duobus commemoratis terremotibus in medium appareret diebus Neapoli in domo cuiusdam egregii simul atque eredutissimi viri, Benedicti Ragusini, amici nostri, ex vera et cetera eius relatione contigisse accepimus. (Manetti, 2012, pp. 123-124)

This kind of connection makes the humanist merchant of Ragusa an active part at the discussion abut the vision of the perfect State.

As has been already said, the two books which are analysed here, touch the problems of the new social class of aristocratic merchant continuously developing which, however, is the economic and even political

\footnotetext{
${ }^{1}$ We know about other two books of Cotrugli gone missing: "De uxore ducenda" wrote in latin about which speaks the author himself at "The book of the art of trade" and another one titled "Della natura dei fiori" reported by Luzatti.
} 
cornerstone of the society. In the process of training of the merchant the family have a relevant role to play. It is impossible to speak about the merchant's position without mentioning the private aspect of his life given that he completes his social function being the father and the governor of his household. His ability and his authority are reflecting directly in his action. Consequently the continuing subsequent of the specific activities entails a plurality of the normative compounds, each one body for the discipline of each specific way of men's being (Nuccio, 2008, p. 494), each of them independent in his complexity, but at the same time coordinate as an inseparable set. In this context, the men's virtue is defined according to his behaviour within his own home, his economical productivity and in the end the compliance with the civil obligation. The laws that organise the family life compile with the one which put in order his public activities. The family space, despite seems to be an autonomous reality separated form the rest of the society, represents a mirror in which the transformation of the worlds existing around the family and the mentality of his member reflects. Therefore the family present themselves as a dynamic manifestation of the social progress and development in the name of the common wealth since the governance of the family on political and theoretical terms is heralding the governance of the State. The search of own identity, the urge to confirm the own dignity through establishing certain rules of behaviour, the model of merchant's life have its roots in the standards of the family life which afterwards become expanded on professional and public merchant's presence. Without comprehending the family reality, it is impossible to give an image of the merchant, designed as a husband and father. In this perspective the choice of the perfect wife revels itself crucial to preserve the entire social class and the values on which its identity is based the moment when the women represents the same merchant (himself). She reflects the conditions of the family and it is she to generate the offspring. Therefore it is of vital importance to define the idea of feminine beauty from the view point of humanistic merchant.

\section{The Women in "De re uxoria" and "Il libro dell'arte di mercatura"}

In the first place, it is necessary to outline the figure of the women in the two analysed books. Regardless of many differences between "De re uxoria" and "The book of the art of trade", they are ideologically close, at least the part which regards the choice of the spouse. Although the authors examine the figure of the wife, the background of the concepts of Barbaro and Cotrugli seems more similar. Both of them perceive the women inferior than the men, reclaiming his right to shaping her in his own image:

(...) la donna è molto fragile et vile criatura, come dice Aristotele che la natura sempre intende produrre maschio ma alcuna volta per alcun difetto di natura produce femina, però la chiama masculo ocasionato. (Cotrugli, 1990, pp. 239-240)

Valent enim viris natura corporis robur et animi datum est, tum aliis de causis, tum ut industria, labore, multis denique periculis domos locupletent; sic (ego assequor coniectura) feminis imbecillitas natura tribuitur, ut quae domi sunt, curiosius ipsae custodiant. (Barbari, 1915, p. 65)

The dignity of the women is created by the men through the marriage:

(...) sacramento che il matrimonio non si separi, advenga che alle volte si facci separatione corporale, come per comune consentimento, per oratione o per religione o per schifar fornicatione, niente di meno lo matrimonio intra li fedeli poi che directamente 'l è contracto et consumato, è inseparabile fino alla morte. (Cotrugli, 1990, p. 243)

(...) Eius institutis nuptiae, quae sacramento, fide, prole firmissimae sunt, sic commendantur, ut prius iussae posterius concessae facile videantur. (Barbari, 1915, pp. 6, 9-10) 
In this perspective getting married lies within the material and ethical—philosophical values which raise the human being over the level of an animal. This concept is a part of the discussion over the dignity of man. The split between the rational and irrational man is clear. It is possible to perceive the christian spirt and the idea of the life aimed at the concrete purpose. The humanistic way of thinking permits what for a christian there is not only a convergence or parallelism between his adherence to religious and his humanistic position but also a harmony and nearly the over-identification (Tenenti, 1996, p. 45).

The choice of the spouse is therefore an act which needs to be controlled to very last detail given the women's role inside the marriage. The virtues which a women must have, a kind of inherent qualities developed subsequently husband's strict surveillance, belong to the aristotelian scale adjusted according female measure:

Et così la donna debbe essere bella, ben constumata, nata d'honesti parenti, non disse mica ricca come la più parte dei moderni giovani, che cercono ricchezze et non mogliera, li quali di poi che l'ànno vivono bene con esse. (...) Debbe la donna essere prudente, costante, grave, patiente, studiosa, humana, modesta, misericorde, pia et religiosa, magnanima, continente, pudica, diligente, sobria, abstinente, sagace et operosa et sempre nello exercitio dello lavorare. (Cotrugli, 1990, pp. 237-238)

Et così della utilità, ma le virtù, cioè è il primo bene, lo quale chiamai bene honesto, sempre dura et vive insieme con la criatura et mai non mancha. (...) Et però riguarda et scegli bene et piglia donna che habbi dote dell'anima, ciò è virtù, le quali, come disse Cicerone, ne per incendio ne per naufragio o altro caso di fortuna non si perdono, et non cambiare il bene perpetuo con transitorio.(Cotrugli, 1990, p. 237)

Veteres, quorum multa doctrina plurimo rerum usu vivit auctoritas, in uxore mores, aetatem, genus, formam, opes spectari debere censuerunt, quae si neglexerimus, et familiae dedecus et dolorem semper, saepe moerorem nobis afferemus; si vero dilegenter observarimus, et domesticae laudi et nostrae dignitati et perpetuae jucunditati consulemus.(Barbari, 1915, p. 32)

The first virtues indicated which become a conditio sine qua non are the beauty, mores, family and the dowry and they are the part of this kind of being present in the society which can define to appear. On this basis it is possible that all the other virtues can be strengthen, in the dose appropriate for the condition of every single human being. It is clarified right away that corporal beauty is not a real good, or rather is not a real beauty:

Però che tre beni sono generalmente in donna. Lo primo è bene honesto, et questo è in le virtù. Lo secondo è bene utile, et queste sono dote, subcesioni et ricchezze, le quali cose non si debbono cercare, ma se ti vengono insieme con l'altre dote del bene honesto non dico che non si debbino pigliare. Terzo è bene delicatbile, et queste sono le bellezze, le quali sono dono di Dio a chi le ha, ma le bellezze passano col tempo, che ogni donna invecchia et diviene bructa, et se l'ai presa per rispeto della bellezza, passando la bellezza passa l'amore. (Cotrugli, 1990, p. 237)

Nam sicut ex paleis facile ignis accenditur, facileque, nisi diutius duratura fomenta subministrentur, evanescit, sic amor inter virum et uxorem specie corporis excitus, nisi lauas ingenii, moris compositio, vitae sanctimonia foverit, paulo post extinguitur. (Barabi, 1915, p. 47)

The corporal beauty, fallen and ephemeral, does not fall into a category of the good and if, what was said earlier, the beauty and the good are the same things, it is possible that it is a real beauty which hinges on honestum, which has the same root of the latin word honestas - beauty. Therefore the real beauty is bounded with moral good and consequently has the capacity to improve the men according to the ciceronian theory revealed in the De officiis. Thus it is not sufficient being statically exposed to the beauty in order to posses the 
virtue but it is necessary to actively participate in the process which revels itself quite complex and consequently requires a range of specific features (Marchese, 2013). The juxtaposition of the honestum and utile is indispensable to make coincide social behaviour, essential for maintaining the common wealth ann moral conduct. From this it follows what the real feminine beauty chairs in the corporal beauty but in the virtue without which neither the marriage nor the society can function properly. It is symbolic that both Barbaro and Cotrugli, among numerous examples of the virtuosos women form the past, use the figure of Penelope to illustrate the ideal model of feminine beauty which glorifies active implementation of the moral good. And then the principle of the active virtue is useful at the pedagogical level because induces to act honestly and is a precious incentive to spread the moral ideals.

Although the position of the women in De re uxoria and in The book of the art of trade is marked, she can not fulfil her role without the support of her husband whereby all her beauty shines. In this way the marriage represents all the virtues valid and useful for the whole community: courtesy, kindness, moderation, total control of the personal instincts in opposition to the bad habits which harm the common wealth. The examples of virtuous women from the past, recalled in both books, fit in the rhetorical structure of exemplum as an universal representation which persuasive force lie in the capacity to transform, through comparison to the past, the linear and open time of the present—-future into a circular one (Ellero, 2007, p. 473). Their utility stands on making a repeatable model of behaviour.

Francesco Barbaro uses the metaphore of the mirror to combat the phenomenon of the search of rich widows by the young Venetian patrician (Fenu, 2012, p. 43), where Cotrugli results more direct and pragmatic. Nevertheless both of them presents the principle of removing (dedocere) what is incorrect and imperfect in the women in order to educate (docere) moves at the philosophical level. The husband then according to the rules of his ars reinvents the women by applying the mimesis concept and making her beauty shine. The creative force revels itself decisive where the nature has not achieved its main objective of perfection. However the diligence and the exercise together with the experience of the doctrine give the result comparable to this of Zeuxis. The husband therefore collects what the nature offers and he improves it getting a perfect statue impeccable at her beauty suitable for her function. In that sense, it is plausible to interpret this kind of ability in the perspective of the human dignity, strictly without immanent reference.

The decorum is the principle adjuster of the virtue and the beauty, especially with regard to the feminine behaviour in public. In this context the beauty expresses itself in the capacity of self-control in every space, both public and private. The due measure, established according to Aristotle by the convenience and the beauty (Irwin, 1996, p. 540), or the modesty comprehended as awareness of limits are factors which regulate the internal harmony of every single elements and make them a beautiful entirety since it appears coherent in her regularity. The women's interior beauty therefore is reflected ${ }^{2}$ in her every gesture, from clothing to the art of conversation. Cotrugli even talks about medicamenta faciei, while Barbaro returns to the concept of modesty and measure with reference to the clothing. This concrete precept's regarding the everyday life, perused with

\footnotetext{
${ }^{2}$ Giovanni Morelli, florentine merchant, dedicates a fragment of his book "Ricordi" to describe the beauty of his sister Mea: "Questa fu di grandezza comune, di bellissimo pelo, bianca e bionda, molto bene fatta della persona, tanto gentile che cascava di vezzi. (...) E con quelle bellezze rispondeano le virtù, ché di sua mano ella sapea fare cio ch'ella volea, che a donna si richiedesse [...]". (Morelli G, 1986, p. 153). The pure white is the exterior symbol of interior beauty, that is to say of the virtue which can be define as a series of the characteristics essential for the women.
} 
costantia e despicentia, make it possible to avoid the danger of degenerate into the bad habit during the way to the virtue. The excess is guilty then of reducing the men into the beast depraving him of the intellect. The rules of the behaviour are based on the utility which conserves in front of the passing of time, making things which otherwise are fallen last. On the other hand the utility is an anchor to lean on during the fight against the Fortune which is a bringer of insecurity. This kind of "etiquette" is created specifically for the women which have a social mission to complete. It is addressed not to the person it concerns to the husbands-masters. This double game of social roles is possible only if takes place between the equal partners. This way it is so important that the real feminine beauty based on the virtue might shine.

The consideration about the virtues is founded on the memory of the great authority of the past. The experience and the memory of the experience, so also the writing, are the basis of the prudence (in the Aristotelian sense of the phrenesis) and of the foresight. They are both the centre of the merchant's universe. In this context the theory of imitatio transplanted on the pedagogical level since both authors use the examples of the virtue women from the past:

Sogliono li heruditi homini non tanto dellectarsi nelle factezze del corpo et della fortuna, quanto della prenstantia d'animo et della virtute, la quale consiste non solamente nell'avere experimentato molte cose, ma etiamdio di quelle che experimentate et intese hanno comandare ala etterna memoria di scripture per seminare doctrina ai posteri. (Cotrugli, 1990, p. 133)

Consilium enim et prudentia, quam veteres usus et memoriae filiam esse voluerunt, nobis necessaria sunt.(Barbari, 1915, pp. 40-41)

The imitatio project itself as principle vehicle of the communication between the men and the external reality, particularly as a founding institution of the moral system, directed into the return of the models from the Ancient. The Seneca's bee is the model of the positive imitation and illustrates the point being inspired by more references in which beauty is perfect in her fullness (Lines, Laureyes, Kraye, 2015, pp. 48-49). In this way the purely pedagogical action is based on the intellectual act which aims to individuate the rules of behaviour to be applied in the new reality.

\section{Leon Battista's Point of View}

Let's take a look at another humanist coming form a merchant family Leon Battista Alberti for whom the family is most important as the only security in the word ruled by the Fortune lacking of absolute certainty. He adopts a similar approach in his Libri della famiglia. His expressive force lies in the form of the treaty chosen by the author which is a dialogue, an exhibition method which in the persuasive speeches boasts a long history. The principle aim of the book, annunciated in the introduction, is to transmit to a future generation a moral legacy based on the concept of the virtue built through the process of aimed education (Bensimon, 2002, p. 32). It takes place within a contact with numerous auctoritas which serve as palpable examples to follow. In this case, the notion of imitatio hinges on two different referential systems: the members of Albertis family and the though of great classics bounded by the emblematic figure of Alberti's father. Everything is closed in the intimate familiar atmosphere, significant to treat subjects related to the examined social group. The choice of the interlocutors, in the perspective of apologia of the domestic dimension of the social and civil reality, is not casual but rather it is aimed at emphasising the didactic structure of the text. On the one side then there are two 
young proponents of the family, Battista and Carlo, the real recipients of the teaching. On the other, Lionardo himself-humanist intermediary between youth and the seniors, Giannozzo - merchant expert of the profession and life, and Adovardo-erudite merchant in whom are both the experience and the knowledge collected. The imitatio, therefore, takes place in terms of hierarchy: the first grade of reference is strictly bounded to the humanistic culture and regards all the knowledge which makes a men an eriudite according to the humanistic standards. Therefore can be inferred the relevance of the classical roots of the education process extended to the women figure. The second grade instead, functions on the level of the experience gained during the whole life and it have to do with the day to day skills. This kind of approach is typical for other merchant treaties which treat the issue of preparation to the profession. The imitatio, then, leads to the complete personal growth only through fatigue and studying which are crucial factors in the process of the men's development. This kind of perceiving the evolution towards the virtue which represents the highest ethic value and final aim, is possible thanks to innate qualities: “(...) discorso e giudizio a seguire e apprendere le cose necessarie e utili, (...) ingegno, docilità, memoria e ragione cose divine e attentissime a investigare, distinguere e conoscere quale cosa sia da fuggire e qual da seguire per ben conservare sé stessi” (Alberti, 1980, p. 163).

According to the men's concept of saint Thomas, the husband, a master whose natural features allow him to discover and to strengthen the potential of the wife, is the bridge by means of which is held the educative process. Even though the figure of the wife in the treaty is a background of the principle topic, she has a predominant role to play in constituting the family, a vital cell in the development of the society. The marriage thus presents itself as a guarantor of a circular movement which assures the continuity of transmitting the experience of the whole generations, almost as if it was in the blood. For this purpose Alberti excludes passion because it is a force which destroys the order:

Non mi stendo a racontare quanta utilità si tragga da questa coniugale amicizia e sodalità, in conservare la cosa domestica, in contenere la famiglia, in reggere e governare tutta la masserizia, le quali tutte cose sono in le donne tali, che forse alcuno stimarebbe per esse essere l'amore coniugale sopra di tutti gli altri interissimo e validissimo. (Alberti, 1980, p. 110).

The matter of the usefulness considerate as an ethic principle in the social and civil context is one of the most relevant aspects in the Alberti's discourse. The main aim of the marriage from viewpoint of the social utility is the search of the virtue and consequently to perform on the women means to perform on the society in order to improve it and to create a civis healthy in every way. The feminine beauty do not lie in the evanescent beauty which annihilates the intellect and leads into the fault and make a men acting like a beast but it do lies in the beauty of the spirit:

Di qui si dice che nel tôr moglie si cerchi bellezze, parentado e ricchezze. (...) Cosi stimo le bellezze in una femmina si possono giudicare non pure ne' vezzi e gentilezza del viso, ma più nella persona formosa e atta a portare e produrti in copia bellissimi figliuoli. E sono tra le bellezze a una donna in prima richiesti i buoni costumi (...). E primi costumi in una donna lodatissima sono modestia e nettezza. (...) Le donne disoneste quanto sieno dannose alle famiglie sia altro luogo da pensare e ragionarne, ché io per me non so quale alle famiglie sia maggiore infelicità o tutta la solitudine, o una disonesta moglie. Adunque nella sposa prima si cerchi le bellezze dell'animo, cioè costumi e virtù, poi nella persona ci diletti non solo venustà, grazia e vezzi (...). (Alberti, 1980, pp. 134-135) 
As in the other two treatise, also in the case of Alberti's spouse the search of the perfect candidate starts from three qualities: the beauty, family connections and the dowry. This triangle, which repeats when talking about women's values, so related to the merchant ones, moves from utility level into the universal one since the beauty is equivalent to the virtue and the ugliness to the sin. The author also lists the physical and personality characteristics which should distinguish the women, worthy of building a merchant's family according to the standards of social system of the time (Grafton, 2002, p. 166). However, the physical beauty is only a pretext to mention nearly philosophical matter of the splendour which is generated by the proportional harmony and balance of this virtue which is destained to never set, forwarded form mother to daughter and improved by the husband in the act of the imitatio. In this way the beauty comprehend as the virtue is on the tip of the scale of the values prepared for the women by the heads of the family, creators and guardians of the moral integrity of the entire social system. ${ }^{3}$

\section{Conclusion}

To conclude, it is relevant that none of the three nominated authors give the physical description of the perfect women, but they limit themselves to delimit generic physical characteristics, conforms to the medical conception of the time. The woman becomes a complete entity only thanks to the creative force of the men who moulds her and gives her the true identity. The man, due to his virtues of the spirit and the intellect, is capable of forming the women in his own image. She is not able to elevate herself on her own because of her defective nature. In the dynamic of the relations between the male and the female, therefore, the beauty has a double role since the women is described through the men's eyes. On the one hand the beauty is only a accessories to the virtue, the main part of the dowry. The spouses reflect in each other and in this context the physical beauty is like a jewel which adorns the women-mirror but can not cover up the real beauty. It lies in both innate and gain values because the spouse has to be the bringer of the merits which make her worthy in front of the male splendor. In this way in the merchant is universe based on the prudence (in the aristotelian sense of the phrenesis) and on the decorum, the true beauty is represented by all the virtues valid and useful for the entire community: courtesy, moderation, discretion, an absolute control of personal instincts in contrast to the bad habit of any kind which harm the common wealth. There appears that the utilitarian function of the beauty has an important role in the formation of the social condition of the merchant-humanist and of his spouse. Cotrugli concentrates, however, on the values of the women which give the utility to the husband, then to the entire social and professional group and, in a larger perspective, to the State, getting close to the Barbaro's ideas. On the other hand, the focal point of his refection on the beauty touches the matter of the perfect citizen and consequently the figure of the women is only the pretext in the discussion about the beauty. Contrary, in the Alberti's Libri della famiglia, the figure of the women is not in the centre of the attention. Her function is limited to a merely utilitarian role in the interest of the family. She is a background of the complex context such as family. Therefore she does not appear on the first plan but she is a foundation on which the fortune of the

\footnotetext{
${ }^{3}$ We can read a similar fragment in the Giovanni Morelli's book "Ricordi". The author, giving advices regarding the spouse to his own male posterity, lists the values of the women which makes her suitable for the marriage. He stars, as Cotrugli, Barbaro and Alberti form the physical restraint, necessary for the conceiving, the family connections and the dowry. Then he draws the image of the aristotelian virtues, examples of the true feminine beauty. In the end Morelli recommended that the women need to be train. It is equivalent to the finial imitatio procedure in the unmilitary perspective. (Morelli, 1986, pp. 167-171).
} 
family is based. Although the idea seems to be similar to one from the De re uxoria, in the I libri della famiglia the focus is moved on the level of the beauty of the spirit. In this perspective the opposition beauty - ugliness is placed on the axis virtue - $\sin$. As can be seen the physical beauty is inherent to the spiritual beauty which is hold by the virtues.

In the nearly utopian and idealistic vision of the family proposed by Francesco Barabo, Leon Battista Alberti and Benedetto Cotrugli a long economic and social evolution of the merchant's class which is based on the concrete action and on the bourgeois value's system is closed. The three authors, trying to define the pluralism of this process, tempt to demarcate the identity of the social class in the continue transformation in order to establish a new existential balance. The social civil ethic is a result of the coordination of the experience matured during the daily contact with the palpable reality and through humanistic background. This is the resin which cements the foundation on which the merchant society of the XV century is based.

\section{References}

Alberti, L. B. (1980). I libri della famiglia (On the family). R. Ruggiero and A. Tenenti (Eds.). Torino: Einaudi.

Aquinas St., T. (2014). Summa Theologica (Summa Theologica). New York: Catholic Way Publishing.

Aristotle, (1959). Ars rhetorica (Rhretoric) (W. D. Ross, Trans.). Oxford: Oxford University Press.

Barbari, F. (1915). De re uxoria liber in partes duas (On marriage). A. Gnesotto (Ed.). Padova: Accademia Patavina di Scienze, Lettere e Arti.

Bianchi, N. (2002). L'immagine paterna come modulo archetipico nei dialoghi in volgare dell'Alberti (Father's image as an archetypal module in Alberti's vernacular dialogues). Albertiana, $V$, 77-88.

Boschetto, L. (2005). Tra Firenze e Napoli. Nuove testimonianze sul mercante-umanista Benedetto Cotrugli e il suo Il libro di arte di mercatura (Florence and Naples. New evidences on the humanist-merchant Benedetto Cotrugli and his "Book of the art of trade"). Archivo Storico Italiano, 606(IV), 697-715.

Bracić, B. (1995). Uno scrittore mercante raguseo del XV secolo: Benedetto Cotrugli e il suo trattato "Della mercatura e del mercante perfetto" (A Ragusian merchant writer of XV century: Benedetto Cotrugli and his treaties "On merchantry and the perfect merchant"). Italica Belgradensia, 4, 121-241.

Chojnacki, S. (2008). Women and men in renaissance venice: Twelve essays on patrician society. Baltimore: The Johns Hopkins Univeristy Press.

Ciceronis, M. T. (1824). Opera. Philosophica III (XVI) (Opera philosophica). Paris: Lefevre Bibliopolam.

Cinti, B. (1965). Della mercatura e del mercante perfetto (On merchantry and the perfect merchant). Studi di lingua e letteratura spagnola, 31, 351-371.

Diodato, R., De Caro, E. \& Boffi, G. (Eds.). (2009). Percorsi di estetica (Paths of beauty). Arte, bellezza, immaginazione (Art, beauty, imagination). Brescia: Morcelliana.

Eco, U. (1987). Arte e bellezza nell'estetica medievale (Art and beauty in the Middle Ages). Milano: Bompiani.

Eco, U. (2005). La storia della bellezza (History of beauty). Milano: Bompiani.

Ellero, M. P. (2007). Aristotele tra Dante e Petrarca: ricezione della Poetica nelle lezioni di Giambattista Gelli all'Accademia Fiorentina (Aristotle between Dante and Petrarch: reception of "Poetics" in the lessons of Giambattista Gelli in the Florentine Academy). Ricerche filosofiche e materiali storico-tesstuali, XIII(2).

Falchetta, P. (2009). Il trattato De navigatione di Benedetto Cotrugli (1464-1465) (Benedetto Cotrugli and his treatise De navigatione). Edizione commentata del ms. Schoenberg 473 con il testo del ms. 557 di Yale (Commented edition of of manuscript Schoenberg 473 with the text of the manuscript 557 of Yale). Studi Veneziani, LVII, 15-335.

Fenu, C. (2012). Oculis uxorem capere: matrimonio «a vista» e ruoli di genere nel De re uxoria di Francesco Barbaro (Oculis uxorem capere: the marriage «on sight» and gender roles in Francesco Barbaro's "On marriage"). Matodi e ricerche, XXXI(2).

Fulińska, A. (2000). Naśladowanie i twórczość (Imitation and creativity). Renesansowe teorie imitacji, emulacji i przektadu (Theories of imitation, emulation and translation in the Renaissance). Wrocław: FNP.

Garin, E. (1981). L'umanesimo italiano. Filosofia e vita civile nel Rinascimento (Italian humanism; philosophy and civic life in the Renaissance). Bari: La Terza. 
Grafton, A. (2000). Leon Battista Alberti: Master Builder of the Italian Renaissance. Cambridge: HUP.

Irwin, T. H. (1996). I principi primi di Aristotele (Aristotle's first principles). Milano: Vita e pensiero.

Kawecki, W. (2013). Teologia piękna. Poszukiewanie logus theologicus w kulturze wspótczesnej (Theology of beauty. Search of logus theologicus in the modern culture). Poznań: Filos Carmeli.

Lines, D. A., Laureyes, M., \& Kraye, J. (Eds.). (2015). Form of conflict and rivalries in reinaissance Europe. Götinngen: Bonn Univeristy Press

Luzatti, M. (1961). Cotrugli, Benedetto (Cotrugli, Benedetto). In Dizionario Biografico degli Italiani (Vol. XXX, pp. 351-371) (In Biographical Dictionary of the Italians). Roma: Istituto dell'Enciclopedia Italiana.

Manetti, G. (2012). De Terremotu (On earthquake). D. Pagliara (Ed.). Firenze: SISMEL.

Marchese, R. (2013). "Quasi quidam ornatus vitae". Il "decorum" nel "De officiis" di Cicerone ( "Quasi quidam ornatus vitae". The decorum in Cicero's "De officiis"). Biblioteca Elettronica su Montesquieu e Dintrni, 5.

Morelli, G. (1986). Ricordi. In V. Branca (Ed.), Mercanti scrittori. Ricordi nella Firenze tra Medioevo e Rinascimento (Merchant writers. Memories in Florence between the Middel Ages and Renaissance). Milano: Rusconi.

Nuccio, O. (2008). La storia del pensiero economico italiano come storia della genesi dello spirito capitalistico (A History of the Italian Economic Thought (As a Genesis of the Capitalistic Spirit). Roma: Luiss University Press.

Seneca, L. A. (1969). Lettere a Lucilio (Letters to Lucilius) ( U. Boella, Trans.). Torino: UTET.

Spremić, M. (1986). Dubrovnik e gli Aragonesi (1442-1495) (Dubrovink and the Aragones). Palermo: Accademia Nazionale di Scienze Lettere e Arti.

Tenenti, A. (1996). La res uxoria tra Francesco Barbaro e Leon Battista Alberti (Res uxoria between Francesco Barbaro and Leon Battista Alberti). In M. Marangono \& S. M. Pastore (Eds.), Una famiglia veneziana nella storia (A venice family in the history). I Barbaro: Atti del Convegno di studi in occasione del quinto centenario della morte dell'umanista Ermolao, Venezia 4-6 novembre 1993 (The Barabros: records of the fith death anniversary of the humanist Ermolao conference, Venice 4-6 November 1993), Venezia: Istituto Veneto di Scienza.

Tucci, U. (Ed.). (1990). Benedetto Cotrugli Raguseo: Il libro dell'arte di mercatura (Benedetto Cotrugli: The book of the art of trade). Venezia: Arsenale Editrice.

Xenophon. (1994). Memorabili (Memorabilia) (A. L. Bonnett, Trans.). Ithaca: Cornell Univeristy Press. 